\title{
When SHOUld Casinos OWe a Duty OF CARE TOWARD THEIR PATRONS?
}

\author{
ERIKA CHAMBERlain, ROBERT SimPSON, \\ AND GARRY SMITH*
}

\begin{abstract}
With the release of the Ontario Court of Appeal's decision in Paton Estate, the possibility was left open for a casino to be found to owe a duty of care to patrons who gamble excessively. This article explores the circumstances under which the Anns/Cooper framework could be applied to find that such a duty exists. Specifically, where the gambler is a member of a casino's customer loyalty program, thereby imputing knowledge of extreme gambling behaviour on the casino, and where the casino has no reason to believe the patron's losses are sustainable, a duty of care should be imposed. Liability should follow in cases where the casino knowingly contributed to or deliberately ignored these losses.
\end{abstract}

\section{TABLE OF CONTENTS}

I. INTRODUCTION ............................. 963

II. THE LEgAL FRAMEWORK FOR GAMBLING IN ONTARIO $\ldots \ldots \ldots \ldots . . .965$

III. BACKGROUND ON GAMBLING-RELATED HARM $\ldots \ldots \ldots \ldots \ldots \ldots . \ldots 66$

A. A Note on "Problem Gamblers" . ............... 966

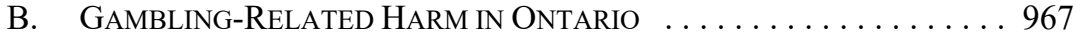

C. Contributing Factors . . . . . . . . . . . . . . . . . . 968

IV. Previous Jurisprudence On The Duty to Prevent

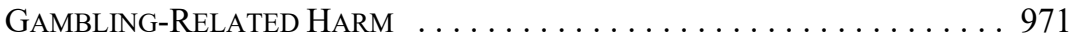

A. Other COMMONWEALTH JURISDICTIONS $\ldots \ldots \ldots \ldots . \ldots . \ldots 97$

B. CANADA ..................................... 974

V. APPLYING THE TEST IN COOPER V. HOBART _.............. 978

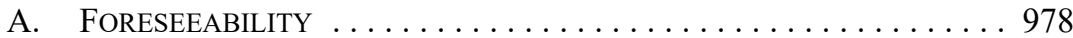

B. Proximity ................................ 979

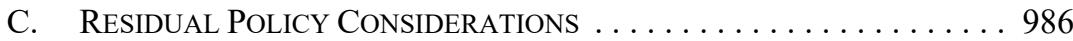

VI. SUMMARY AND CONCLUSIONS $\ldots \ldots \ldots \ldots \ldots \ldots \ldots \ldots \ldots . \ldots . \ldots . \ldots$

\section{INTRODUCTION}

Until 2016, reported negligence claims against casinos had largely been unsuccessful, both in Canada and in other common law jurisdictions. However, in Paton Estate v. Ontario Lottery and Gaming Corporation (Fallsview Casino Resort and OLG Casino Brantford), ${ }^{1}$ a majority of the Ontario Court of Appeal refused to strike out a claim against the Ontario Lottery and Gaming Corporation (OLG) by two estates that had been defrauded by a putative gambling addict. ${ }^{2}$ While the Court conceded that "casinos cannot be expected to conduct an

Erika Chamberlain, LLB, PhD (Cantab), Professor and Dean, Faculty of Law, University of Western Ontario; Robert Simpson, MA (Social Welfare Policy), Principal, Sagewood Resources; Garry Smith, Professor Emeritus, University of Alberta. The authors would like to thank Professor Anna Lund and two anonymous reviewers for their helpful comments, and Don Roberto, Western Law JD Candidate 2020, for his research assistance.

12016 ONCA 458 [Paton Estate CA], rev'g 2015 ONSC 3130 [Paton Estate SC].

2 In addition to negligence, the plaintiffs made claims in knowing receipt and unjust enrichment. A majority of the Court of Appeal allowed these claims to proceed as well. 
individualized assessment of each of their customers to determine the wisdom of the decision to gamble," it suggested that "more may be expected when an individual is obviously addicted to gambling and out of control."3 This decision potentially opens the door to claims falling within such exceptional factual circumstances. In this article, we explore those circumstances and suggest when a duty of care ought to be imposed. ${ }^{4}$

Novel duties of care in Canada are assessed using the test outlined by the Supreme Court of Canada in Cooper v. Hobart, ${ }^{5}$ and elucidated in numerous cases over the last 15 years. ${ }^{6}$ This test has three main components: foreseeability, proximity, and so-called "residual" policy considerations. Our analysis of the proposed duty owed by casinos to prevent and intercept gambling-related harm proceeds in accordance with this test. Research demonstrates that harm is a reasonably foreseeable consequence of casino gambling at extreme levels. ${ }^{7}$ Moreover, given casinos' detailed tracking of gambling by loyalty program members, they are in a proximate relationship and stand to profit by taking advantage of them.

In terms of residual policy considerations, the most likely arguments against casino liability will be that imposing a duty of care would give rise to indeterminate liability and create an "insurance scheme" for all patrons who suffer financial loss due to gambling. Moreover, any damages will be paid from casinos' and OLG's operating expenses, and hence reduce the revenue ultimately paid to the government. ${ }^{8}$ In addition, it has been considerably more difficult to establish a duty of care with respect to pure economic loss than for physical injury or property damage. Nonetheless, we argue that the exploitative practices of casinos and the personal and social harm attributable to extreme gambling justify the imposition of a duty of care in certain circumstances.

This article outlines the tactics used by Ontario casinos to induce patrons to increase the monetary amounts and time spent gambling, and describes the personal and social harm that can result. ${ }^{9}$ We argue that these tactics knowingly and actively create a dangerous situation for patrons, and thereby justify the imposition of an affirmative duty to prevent harm resulting from excessive gambling consumption. Based on these factors, we compare the

Paton Estate CA, supra note 1 at para 35.

This topic was the focus of a well-known exchange in 2007: William V Sasso \& Jasminka Kalajdzic, "Do Ontario and Its Gaming Venues Owe a Duty of Care to Problem Gamblers?" revised version (Guelph: Ontario Problem Gambling Research Centre, 2007); Jamie Cameron, "Problem Gamblers and the Duty of Care: A Response to Sasso and Kalajdzic" (2007) 11:5 Gaming L Rev 554. There has been considerable jurisprudence on both gambling-related harm and the duty of care more generally in the ensuing decade.

2001 SCC 79 [Cooper].

See especially Odhavji Estate $v$ Woodhouse, 2003 SCC 69; Childs v Desormeaux, 2006 SCC 18 [Childs]; Hill v Hamilton-Wentworth Regional Police Services Board, 2007 SCC 41 [Hill]; Fullowka $v$ Pinkerton's of Canada Ltd, 2010 SCC 5 [Fullowka]; Deloitte \& Touche v Livent Inc (Receiver of), 2017 SCC 63 [Livent].

$7 \quad$ Robert J Williams et al, "Quinte Longitudinal Study of Gambling and Problem Gambling” (Guelph: Ontario Problem Gambling Research Centre, 2015), online: $<$ hdl.handle.net/10133/3641>.

8 The Government of Ontario is the sole shareholder of OLG, which reports to the Minister of Finance. See generally Ontario Lottery and Gaming Corporation Act, 1999, SO 1999, c 12, Schedule L. In this capacity, it receives residual revenues from gambling after operating expenses are paid; this amounts to about 33 percent of total revenue net of winnings (Ontario Lottery and Gaming Corporation, Annual Report 2017-18 (Toronto: OLG, 2018) at 4, 12 [OLG, Annual Report].

9 We have focused our discussion on Ontario on account of the decision in Paton Estate and in order to avoid comparison of the various provincial statutory schemes; however, the general principles of negligence that we discuss are largely transferable across the provinces. 
potential duty of care owed by casinos to the established category of commercial alcohol providers in relation to excessive alcohol consumption by their patrons.

We also review the jurisprudence from Canada and other Commonwealth jurisdictions, which provides guidance on the circumstances that might give rise to a duty of care in negligence. (The potential liability in contract, unjust enrichment, or for intentional torts is deserving of a separate analysis. ${ }^{10}$ ) On the premise that liability will likely be restricted to exceptional circumstances, we believe that a duty of care should be imposed where the plaintiff is: a high-loss patron, a loyalty program member whose tracking data indicates the probability of imminent or existing harm, and someone for whom the casino has failed to intervene to prevent further loss (or has endeavoured to induce additional excessive gambling). It is ultimately our hope that, just as commercial host liability has inspired more responsible serving practices at licenced establishments, the potential for negligence liability will provide an incentive for casinos to better monitor and control excessive gambling and harm-inducing practices. ${ }^{11}$

\section{The Legal FramewOrK FOR GAMbling in ONTARio}

Although gambling is prohibited by Canada's Criminal Code,$^{12}$ an exemption exists for lottery schemes that are operated by provincial governments in accordance with provincial legislation. ${ }^{13}$ In Ontario, gambling is regulated through the Gaming Control Act, 1992, ${ }^{14}$ which sets out the conditions for registered suppliers and licensees, and the Alcohol, Cannabis and Gaming Regulation and Public Protection Act, $1996 .{ }^{15}$ It is not necessary to explain this structure in detail here; the province has essentially created a system whereby private operators are contracted to run commercial casinos and, after operating expenses and allowed profits have been deducted, transfer the balance to OLG. ${ }^{16}$

In terms of the duty of care, this arrangement means there are two separate but closely related potential defendants: casinos and OLG. Casino operators directly interact with patrons and actively monitor the play of loyalty program members; together, these activities create a proximate relationship with potential plaintiffs. OLG, on the other hand, is the public

See e.g. Ian Freckelton, "Pathological Gambling and Civil Actions for Unconscionability: Lessons from the Kakavas Litigation," Case Comment, (2013) 20:4 Psychiatry, Psychology \& L 479; Rick Bigwood, "Still Curbing Unconscionability: Kakavas in the High Court of Australia," Case Comment, (2013) 37:2 Melbourne UL Rev 463.

11 In his book, Permit but Discourage: Regulating Excessive Consumption (New York: Oxford University Press, 2011) at 332, WA Bogart expresses skepticism about the utility of civil litigation in reducing problem gambling and warns that a focus on litigation may detract from other, more effective countermeasures. While we agree that other countermeasures are needed, we believe that civil liability is nevertheless an important consequence for predatory casino practices and could provide the financial incentive to introduce more responsible practices. See also Pekka Sulkunen et al, Setting Limits: Gambling Science and Public Policy (Oxford: Oxford University Press, 2019).

RSC 1985, c C-46, ss 201-202, 206.

Ibid, s 207.

SO 1992, c 24 .

SO 1996, c 26 [ACGRPPA].

In 2012, OLG unveiled a plan for new and enlarged casinos run by private operators to be established in 29 designated "zones" across the province, and projected additional annual revenues of \$1.3 billion to government by 2017-18. See Ontario Lottery and Gaming Corporation, Modernizing Lottery and Gaming in Ontario: Strategic Business Review/Advice to Government (Toronto: OLG, 2012) at 9 [Modernization Plan]. OLG's 2017-18 Annual Report stated that revenue to the Government of Ontario was $\$ 2.49$ billion, an increase of $\$ .57$ billion over the 2011-12 base of $\$ 1.92$ billion. See OLG, Annual Report, supra note 8 at $4,23$. 
owner and partial regulator of gambling in Ontario and is charged under the Criminal Code to "conduct and manage" the provision of gambling. ${ }^{17}$ To avoid duplication, we have endeavoured to combine factors relevant to the liability of operators and regulators wherever possible. ${ }^{18}$ Of note, we consider the provincial government's potential liability for its overall regulation of the gambling industry to be beyond the scope of this article. ${ }^{19}$

\section{BACKGROUND ON GAMBLING-RELATED HARM}

\section{A. A Note ON "Problem Gamblers"}

Much of the jurisprudence and academic literature on the potential liability of casinos relies on specific definitions of "problem," "pathological," "disordered," "compulsive," or similarly-labelled gamblers. ${ }^{20}$ Although these definitions are important in the treatment context, we do not believe that the potential duty of care rests on the identification of a particular psychological condition. Indeed, we believe that arguments about the definition of problem gambling distract attention from the more critical issue, as they lead to counterarguments that casino operators cannot be expected to diagnose such conditions. ${ }^{21} \mathrm{We}$ agree that clinical diagnoses are beyond the expertise of casino operators, but our argument does not rest on the plaintiff having a particular diagnosis.

Our argument begins with an appreciation that commercial host liability is based on the plaintiff being over-served alcohol to the point where harm is reasonably foreseeable. In this regard, the plaintiff's status as a "problem drinker" or "alcoholic" is irrelevant. Rather, the issue is about the commercial host permitting excessive consumption ${ }^{22}$ or serving a patron

The then Ontario Lottery Corporation retained the law firm of Morris, Rose \& Ledgett to provide a legal analysis of Ontario's gambling market. The resulting 1996 report, Review of Gaming Legislation in Ontario, identified the practice of contracting private sector corporations to run casinos as a violation of the "conduct and manage" provisions in section 207(1)(a) of the Criminal Code. The report concluded that only provincial governments have a Criminal Code exemption to conduct and manage lottery schemes, and that this authority could not be delegated to another party. The report is summarized in Colin S Campbell, Timothy F Hartnagel \& Garry J Smith, The Legalization of Gambling in Canada (Ottawa: The Law Commission of Canada, 2005) at 52-54.

18 The most plausible claims against OLG as a regulator would be where it failed to adequately monitor casinos and enforce regulations, thereby allowing predatory practices to continue. Even still, it could be difficult to establish a proximate relationship between individual gamblers and OLG, as there are no direct interactions between them and OLG would argue that it has to balance competing interests (such as the financial viability of casinos and the interests of the province as a whole). Similar arguments have been successfully employed by other regulators, even in cases involving physical harm. See e.g. Williams $v$ Ontario, 2009 ONCA 378 (arising out of the SARS outbreak in 2003); Attis v Canada (Minister of Health), 2008 ONCA 660 (approval by defendant of unsafe breast implants).

19 This regulatory liability, which would presumably be directed toward the Alcohol and Gaming Commission of Ontario, would arise on different principles. To the extent that an alleged duty would rely on the province's overall policy with respect to gambling, it would most likely give rise to policy immunity in accordance with $R v$ Imperial Tobacco Canada Ltd, 2011 SCC 42. See generally Peter W Hogg, Patrick J Monahan, \& Wade K Wright, Liability of the Crown, 4th ed (Toronto: Carswell, 2011) ch 11; Bruce Feldthusen, "Public Authority Immunity from Negligence Liability: Uncertain, Unnecessary, and Unjustified" (2013) 92:2 Can Bar Rev 211.

20 See e.g. Freckelton, supra note 10; Calvert $v$ William Hill Credit Ltd, [2008] EWHC $454(\mathrm{Ch})$ at para 106, aff'd [2008] EWCA Civ 1427 [Calvert]. See also National Centre for Responsible Gaming, "What is Problem Gambling or Gambling Disorder?" online: <www.ncrg.org/press-room/media-kit/faq/whatproblem-or-pathological-gambling $>$.

21 See especially Cameron, supra note 4 at 557-58; and the Australian cases discussed in Part IV.A, below. The Liquor Licence Act Regulations, RRO 1990, Reg 719, s 45(1) state that licensees "shall not permit drunkenness," where the word "permit" has been interpreted by the provincial regulator as meaning "fail to prevent," thereby specifying that licensees "shall not fail to prevent drunkenness." See Re Sand Bar, [1999] OAGCD No 64 (QL) at para 34; Re Heart \& Crown Pub \& Restaurant, [1999] OAGCD No 288 (QL) at para 33. 
who has already consumed excessively. ${ }^{23}$ In similar fashion, we contend that casino liability should be based on the plaintiff's excessive "consumption" of gambling, irrespective of diagnosed psychological status, where analogous thresholds indicate the reasonable foreseeability of harm. In this respect, it is noteworthy that gambling-related harm, like alcohol-related harm, is not limited to so-called problem gamblers or problem drinkers but spread across the population of consumers. ${ }^{24}$

\section{B. GAMBLING-RELATED HARM IN ONTARIO}

The burden of gambling-related harm is by no means small or insignificant: across all forms of gambling there are an estimated 231,000 problem gamblers in Ontario, half of whom are married and, on average, have one child, who will share the burden of their gambling. ${ }^{25}$ Excessive gambling has a wide range of financial, legal, social, and health consequences. Financially, it is not uncommon for excessive gamblers to deplete their savings, retirement funds, and other investments. They may borrow from family and friends and extend multiple credit cards to maximum limits. Others borrow against the equity in their homes or businesses or deplete secured lines of credit. It has been estimated that gamblers in Ontario account for over 10,400 bankruptcies each year, or about 20 percent of all consumer insolvencies in the province. ${ }^{26}$ Of further concern, they are susceptible to taking money to which they have access but lack legal or moral authority to spend, as was the case in Paton Estate. Such behaviour is often rationalized by gamblers through intentions to replace misappropriated funds as soon as their luck changes and they have a substantial win.

Excessive gamblers also report mental health problems, relationship issues, and neglect of family. About 2.2 percent had suicidal thoughts and 1.1 percent were divorced due to gambling. ${ }^{27}$ While this is admittedly a small percentage, it does extrapolate to over 5,000 individuals in Ontario contemplating suicide and over 2,500 separations or divorces annually. ${ }^{28}$ Accordingly, we believe that the losses associated with excessive gambling are not purely economic, nor are they borne by the gambler alone. ${ }^{29}$

See the Ontario Liquor Licence Act, LSO 1990, c L19, s 29, which prohibits the sale or supply of alcohol to a person who is or appears to be intoxicated. This prohibition applies regardless of where the person has been drinking, that is, even if a patron arrives at a bar having become intoxicated at another commercial or private location.

24 A 2017 New Zealand study, which quantified the burden of gambling-related harm, found that the total burden of harm extended across all gamblers, with 48 percent attributed to low-risk gamblers, 34 percent to moderate-risk gamblers, and 18 percent to problem gamblers. See New Zealand Ministry of Health, Measuring the Burden of Gambling Harm in New Zealand by Matthew Browne et al (Wellington: Ministry of Health, 2017) at 192, online: <www.health.govt.nz/publication/measuring-burden-gamblingharm-new-zealand $>$. A similar phenomenon is found among drinkers where the nature of harm is less severe in the non-alcoholic population, but the substantially greater number of people in that category results in a larger contribution to the overall burden. See generally E Chamberlain \& R Solomon, "The Tooth Fairy, Santa Claus, and the Hard Core Drinking Driver" (2001) 7:4 Injury Prevention 272. See also Institute of Medicine, "Broadening the Base of Treatment for Alcohol Problems" (Washington: National Academy Press, 1990).

25 Robert J Williams \& Rachel A Volberg, "Gambling and Problem Gambling in Ontario" (Ontario Problem Gambling Research Centre and the Ontario Ministry of Health and Long Term Care, 2013) at 42-43. Problem gamblers, as measured in surveys and studies, represent only a portion of total gambling-related harm; however, the severity of each case is likely to be highest in this population. Ibid at 50,58. This figure is based on the results of a provincial telephone survey conducted in 2010-2011, wherein 4.5 percent of problem gamblers reported filing for bankruptcy (ibid). Ibid at $50-51$.

Ibid at 50 .

See also Edward A Morse \& Ernest P Goss, Governing Fortune: Casino Gambling in America (Ann Arbor: University of Michigan Press, 2007) at ch 5. 
From the province's perspective, so-called "problem gamblers" account for about 24.1 percent of gambler expenditures overall, including nearly 57 percent of expenditures on casino table games and over 31 percent on slot machines. ${ }^{30}$ Thus, revenue derived from those experiencing the greatest harm in the province is substantial, amounting to $\$ 1.8$ billion in 2017-2018. ${ }^{31}$ This is relevant to the comparison between casinos and alcohol providers, both of which stand to profit from the encouragement of harmful behaviour. This profit incentive puts both the province and individual casinos in an apparent conflict of interest.

\section{CONTRIBUting FACTORS}

Given the seriousness of gambling-related harm, it is vital to appreciate the factors that contribute to excessive consumption; these can be both internal and external to the individual.

\section{INTERNAL CONTRIBUTING FACTORS}

Three risk factors within the individual contribute to excessive gambling: erroneous cognitions, risk practices, and preoccupation. Erroneous cognitions encompass beliefs (for example, that the gambler can predict or influence outcomes) and motivations (for example, to win money or win back money), both of which enable and support excessive gambling. Risk practices directly increase the likelihood of excessive consumption. Examples include chasing losses and employing "winning systems" touted to tip odds in favour of the patron. Preoccupation entails spending an inordinate amount of time thinking about gambling (for example, how to spend jackpots, or planning and orchestrating gambling sessions).

Individually and in combination, internal factors contribute to excessive gambling and predict the onset and escalation of harm. ${ }^{32}$ In this regard, excessive gambling is reflected in the frequency and duration of gambling sessions, average bet size, and amounts lost both per session and cumulatively, all of which are rigorously monitored by casino loyalty programs.

Tony Schellinck et al, "Development of an Instrument for Identifying Risk for Problem Gambling among Slot Machine Gamblers in Ontario" (2011), online: Focal Research <https://www. focalresearch.com/sites/default/files/publications/2755_FLAGS\%20Post $\% 20$ Review\%20Final $\% 20$ Report\%20April\%202011\%5B1\%5D.pdf>. 


\section{EXTERNAL CONTRIBUTING FACTORS}

Three additional contributing factors ${ }^{33}$ are located within casino environments: intermittent reinforcement and volatility, deceptive game design and operating practices, and loyalty programs. ${ }^{34}$ These factors capitalize on the house advantage by increasing the frequency and duration of play and bet size.

Intermittent reinforcement is provided by random periodic wins that are designed into slot machines and integral to table games. These wins function as psychological motivators to sustain gambling in the face of mounting losses, when patrons would otherwise have quit. Volatility is the tendency of random outcomes to clump into winning and losing "streaks." Winning streaks, which at times may be significant, instill patron self-perceptions of being lucky or charmed. Equally important, such streaks can establish beliefs that they will recur, a conviction that supports loss-chasing. Conversely, losing streaks can be devastatingly large (for example, exceeding \$1 million per day) and dramatically escalate cumulative losses.

Deceptive game design is built into electronic gambling machines (EGM) (slot machines and video lottery terminals) in order to shape patrons' perceptions in ways that will sustain and extend gambling. ${ }^{35}$ For example, Ontario slots display "near misses" (that is, winning outcomes immediately above or below the pay line) 12 times more frequently than actual wins occur, ${ }^{36}$ giving the false impression that a win is imminent. ${ }^{37}$ Additionally, they frequently emit "winning" sounds when the payout is less than the amount bet (known as "losses disguised as wins"), promoting inaccurate impressions of frequent wins and raising patrons' anticipation of personal success. ${ }^{38}$ In another example, slots offer multi-line play (up to 15 lines simultaneously), permitting much higher bets than the advertised currency (for example, a $\$ 0.25$ machine could allow for a $\$ 3.75$ bet). On winning spins where the bet was less than the maximum, pop-up messages indicate what would have been won had the maximum bet been made. ${ }^{39}$

Deception is further incorporated into operating practices. For example, staff will hold specific machines while patrons take a break (so that others cannot "steal" an imminent win)

Additional external factors, which are beyond the scope of this article, but nonetheless influential, include marketing and advertising practices, the normalization of high-stakes gambling, casino "front end" accounts, and extending credit to patrons. On this last factor, see Lisa Priest, "The Million-Dollar Club: Losing Big, Losing Often," The Globe and Mail (5 October 2009) (indicated that credit was extended to 5,680 patrons between 2000 and May 2009, for a total of $\$ 86.8$ million).

34 Natasha Dow Schüll, Addiction by Design: Machine Gambling in Las Vegas (Princeton: Princeton University Press, 2012).

35 A class action based on deceit and failure to warn with respect to EGMs was recently certified in Newfoundland and Labrador: Atlantic Lottery Corporation Inc - Société des loteries de l'Atlantique v Babstock, 2018 NLCA 71, leave to appeal to SCC granted, 38521 (23 May 2019). See also Bogart, supra note 11 at 301-304, which explains that EGMs are disproportionately associated with problem gambling and have accordingly been banned in some jurisdictions.

36 This is expressly permitted by Ontario's gambling regulations: Alcohol and Gaming Commission of Ontario, Electronic Gaming Equipment Minimum Technical Standards (Toronto: AGCO, 2017), s 20.5.1.

37 Jeffrey I Kassinove \& Mitchell L Schare, “Effects of the 'Near Miss' and the 'Big Win' on Persistence at Slot Machine Gambling” (2001) 15:2 Psychology Addictive Behaviors 155 at 157.

38 Mike J Dixon et al, "Losses Disguised as Wins in Modern Multi-Line Video Slot Machines" (2010) 105:10 Addiction 1819 at 1823. See also Mike J Dixon et al, "Using Sound to Unmask Losses Disguised as Wins in Multiline Slot Machines" (2015) 31:1 J Gambling Studies 183.

39 Kevin Harrigan et al, "Games of Chance or Masters of Illusion: Multiline Slots Design May Promote Cognitive Distortions” (2014) 14:2 Intl Gambling Studies 301. 
or will point out machines that "have not won in a while." ${ }^{\prime 4}$ Both reinforce the erroneous belief that wins are more likely after a string of losses. At the tables, casinos make notepads available for patrons to record outcomes and further turn a blind eye to those using theoretical "winning systems" (all of which increase the rate of loss). ${ }^{41}$ Individually and collectively, deceptive features in casinos are explicitly intended to increase "spend" and "time in seat," in-house euphemisms for maximizing revenue. ${ }^{42}$

Loyalty programs are solely designed to increase the amounts gambled and lost. Dollars gambled "earn" reward points, which can be exchanged for parking, meals, spa services, gifts, and so on. To move up to increasingly attractive perks, loyalty program members are encouraged to aspire to "tiers" through increased gambling. To illustrate, one Ontario casino requires $\$ 20,000$ in slots play every six months to qualify for "gold" status and $\$ 100,000$ over the same period to qualify for "platinum" status. ${ }^{43}$ Thus, tiers simultaneously normalize, encourage, and aggrandize excessive gambling consumption.

In addition, casinos introduce unsolicited "comps" to high spending loyalty program members (for example, limousine transportation, "unclaimed" luxury hotel suites, invitationonly tournaments, VIP seats at casino shows, and time-limited "matched play" coupons of up to $\$ 500) .{ }^{44}$ Account managers are assigned to accompany such members throughout their stay and initiate offers for additional comps (for example, staying in the presidential suite instead of returning home). All stimulate casino attendance when visits were not otherwise planned or extend the duration of gambling while there.

Loyalty programs are antithetical to harm prevention in that they offer increasingly powerful inducements as patrons' monitored gambling metrics increase and reserve the most powerful inducements for those whose gambling is most extreme. These patrons represent only a small proportion of the loyalty program membership but are crucial to the casino's revenue base. ${ }^{45}$ Indeed, the Australian Productivity Commission gained access to a casino loyalty program database and found that 2.3 percent of members generated 76 percent of the revenues, unambiguously quantifying the goal of generating revenue from the extreme highloss patrons. ${ }^{46}$

Loyalty programs are a critical aspect of the duty of care analysis in claims against casinos. Defendants maintain that their employees are not qualified to make clinical diagnoses and, therefore, could not be aware of the plaintiff's problem gambling. They Ontario casino.

Nigel E Turner \& Roger Horbay, "Doubling Revisited: The Mathematical and Psychological Effect of Betting Strategy" (2003) 15:2 Gambling Research 16 at 20

Schüll, supra note 34 at $58-59$.

43 See Fallsview Casino Resort, "Players Advantage Club," online: <www.fallsviewcasinoresort.com/ players-club $>$. See also Casino Rama, "Players Passport Club," online: <www.casinorama.com/ Reward/How-It-Works.aspx $>$.

The provision of comps is only loosely regulated. See Bogart, supra note 11 at 313-14.

Williams \& Volberg, supra note 25 at 7-8.

Australia, Commonwealth, Productivity Commission, Gambling: Productivity Commission Inquiry Report, vol 2 (Canberra: Productivity Commission, 2010) at B.21-B.22. See also Gary Banks, "Evidence and Social Policy: The Case of Gambling" (Speech delivered to the South Australian Centre for Economics, Adelaide, 30 March 2011), online: <https://www.pc.gov.au/news-media/speeches/ evidence-and-social-policy-gambling/evidence-and-social-policy-gambling.pdf $\$$. 
further argue that they have no way of knowing whether plaintiffs were gambling beyond their means. As mentioned, however, the likelihood of harm is tied to gambling consumption, irrespective of clinical status, ${ }^{47}$ and loyalty programs provide precise records about patrons' betting patterns and levels. Embedded within these metrics is gambling that is well beyond the means of the average patron and, in some instances, beyond the means of all but the highest income brackets. ${ }^{48}$ Licenced alcohol providers have a legal duty to monitor consumption so that they do not over-serve patrons. Similarly, casinos should have a duty to monitor loyalty program data in order to intercept excessive consumption that may indicate reasonably foreseeable harm. Loyalty programs provide ample means to do so indeed, they provide far more detailed data about gambling consumption than anything available to licenced alcohol providers.

Finally, external factors accelerate gambling consumption in an environment devoid of corresponding restraint mechanisms. Accordingly, patrons who gamble excessively might reasonably be seen as those who respond exactly as intended. Thus, excessive gambling and resulting harm are inevitable by-products of the manner in which casinos are designed and operated; in terms of negligence, harm is reasonably foreseeable.

\section{Previous Jurisprudence on the Duty to Prevent Gambling-Related HaRm}

\section{A. Other CommonWealth JURISDictions}

Outlined below is the pertinent law in other Commonwealth jurisdictions ${ }^{49}$ for the purposes of providing context; ${ }^{50}$ however, we do not believe that these foreign authorities should be determinative of claims in Canada. In particular, the Canadian courts have long been more willing to impose duties of affirmative action, including the duties owed by commercial alcohol providers (described below), the duty to rescue, ${ }^{51}$ and the duty to warn or protect potential crime victims. ${ }^{52}$ Further, unlike their counterparts in the United Kingdom and Australia, Canadian courts have typically been unpersuaded by arguments based on

Horsley v MacLaren (1971), [1972] SCR 441.

Jane Doe v Metropolitan Toronto (Municipality) Commissioners of Police (1998), 39 OR (3d) 487 (Gen

Div); Fullowka, supra note 6.

See Cameron, supra note 4.

Statistics Canada reports that gamblers in the highest income quintile (annual household income of $\$ 80,000$ and above) spend 0.4 percent of their income on gambling, amounting to about $\$ 620$ annually. See Statistics Canada, "Gambling," Perspectives on Labour and Income, Catalogue No 75-001-X (Ottawa: Statistics Canada, July 2009) at Table 5. Applying this same percentage to the top 0.01 percent of income tax filers in Ontario (in 2015, these 1,190 individuals earned an average of \$7.3 million), they would have to spend 13.7 percent of their annual income on gambling to afford an annual loss of $\$ 1$ million. See Statistics Canada. "High Income Tax Filers in Canada," Table 11-10-0055-01 (Ottawa: Statistics Canada, 2015).

We omit the American jurisprudence because the analysis of the duty of care in general is markedly different from that in Commonwealth jurisdictions. Gamblers who have sued casinos for their losses have so far been unsuccessful in the United States. See generally Irina Slavina, "Don't Bet on It: Casinos' Contractual Duty to Stop Compulsive Gamblers from Gambling” (2010) 85:1 Chicago-Kent L Rev 369 (which examines casinos' liability for breach of contract with respect to self-exclusion agreements). Claims based on negligence or an extension of so-called "dramshop" liability (such as the statutory liability of alcohol providers) have either failed or stalled before reaching final judgment: John Rosengren, "How Casinos Enable Gambling Addicts" The Atlantic (December 2016) at 23.

A useful (though somewhat outdated) summary can also be found in Joseph M Kelly \& Alex Igelman, "Compulsive Gambling Litigation: Casinos and the Duty of Care" (2009) 13:5 Gaming L Rev and Economics 386. 
personal autonomy or individual responsibility, especially in situations where the plaintiff's ability to make independent decisions may be compromised by alcohol or other forms of excessive consumption. Finally, we note that the legislative framework governing gambling in some of these jurisdictions is considerably more permissive than what exists in Canada. ${ }^{53}$ Their reluctance to recognize a duty of care reflects, to an extent, this more laissez-faire cultural attitude. $^{54}$

The leading English case on gambling-related liability is Calvert v. William Hill Credit Ltd. ${ }^{55}$ In that case, the plaintiff's betting activities were largely conducted by telephone (at least, once his gambling became excessive) and made use of a customer account. He placed multiple bets on several occasions, staking hundreds of thousands of pounds in a single day. Such betting activity came to the attention of the company's risk managers. He requested closure of his account on several occasions but was allowed to re-open it despite cautionary notes in his file. Ultimately, he requested entry into a self-exclusion agreement, which was intended to prohibit him from reopening an account for six months; unfortunately, due to the defendant's negligence, the agreement was not implemented. He suffered significant losses (likely over $£ 1$ million) to the defendant following his purported self-exclusion.

In a lengthy judgment, Justice Briggs assessed the duty of care in light of several important considerations, including that the losses were primarily economic ${ }^{56}$ and selfinflicted. ${ }^{57}$ Thus, the claim ran up against the traditional English presumption against imposing a duty. Justice Briggs quoted Lord Hoffmann from Reeves v. Commissioner of Police of the Metropolis: "It reflects the individualist philosophy of the common law. People of full age and sound understanding must look after themselves and take responsibility for their actions." ${ }^{58}$ Accordingly, special circumstances would need to be present before a duty of care could be imposed. Justice Briggs found that the defendant's assumption of responsibility and ability to control the plaintiff's telephone betting was sufficient to create a limited duty of care for the six-month period during which the self-exclusion agreement ought to have been in operation. (He rejected the plaintiff's broader submission that a duty of care is owed to problem gamblers. $\left.{ }^{59}\right)$ Nevertheless, the plaintiff's claim failed on the issue of causation: Justice Briggs concluded that, even if the defendant had prevented the plaintiff from making telephone bets for six months, the plaintiff would have found other gambling

For instance, England did not have gambling regulations until the Gambling Act 2005, (UK), c 19. In Australia, gambling machines are widely available in pubs, bars, and clubs; however, legislation was recently introduced to curb online gambling: Interactive Gambling Amendment Bill 2016 (Cth). While Commonwealth courts have been reluctant to rule against casinos and gambling clubs, an Austrian court ruled in favour of a gambler in 2004. See Michael Leidig, "Gambling Addict Wins a Fortune in Court Ruling Against Casino," The Telegraph (22 February 2004), online: <www. telegraph.co.uk/news/worldnews/europe/austria/1455090/Gambling-addict-wins-a-fortune-in-courtruling-against-casino.html>.

Supra note 20.

The plaintiff also claimed for some psychiatric harm.

While this is a common characterization by the courts in England and Australia, we would argue that the inducements and disinformation tactics employed by casinos, which are specifically designed to maximize gambling losses, undermine the suggestion that such losses are "self-inflicted." (1999), [2000] 1 AC 360 at 368 (HL Eng)), quoted in Calvert, supra note 20 at para 146.

Calvert, ibid at paras $167 \mathrm{ff}$. Among other reasons, Justice Briggs cited the challenges posed by the need for bookmakers to identify pathological gamblers. As noted in Part III.A, above, we believe that the duty of care should not be defined by reference to psychological conditions, but by the over-consumption of gambling. 
venues and would still have suffered financial ruin. ${ }^{60}$ The Court of Appeal denied the plaintiff's appeal on the causation issue.

Several Australian cases have also considered the potential negligence liability of casinos. In Reynolds v. Katoomba RSL All Services Club Limited, ${ }^{61}$ the New South Wales Court of Appeal dismissed a claim from an addicted gambler who had pleaded for the defendant not to cash his cheques or advance credit to him, given his lack of self-control. The Court vigorously stressed the plaintiff's autonomy and responsibility for his own actions. Chief Justice Spigelman warned that " $[\mathrm{t}]$ his Court should be very slow indeed to recognise a duty to prevent self-inflicted economic loss. Loss of money by way of gambling is an inherent risk in the activity and cannot be avoided." ${ }^{22}$ Following a discussion of vulnerability, Chief Justice Spigelman also noted that, although the defendant was aware of the plaintiff's susceptibility to gambling, it was within the plaintiff's own power to resign from the club or at least stay away from it. ${ }^{63} \mathrm{He}$ could not "shift his personal responsibility for his own actions to the club." ${ }^{64}$ Justice Giles also suggested that a duty of care would harm the plaintiff's right "to gamble at the club and to spend his money in gambling rather than on other avenues of gratification and, if he chooses, to enter into debt so that he can do so." ${ }^{65}$ Further, it would be difficult for the club to distinguish when the plaintiff was engaged in compulsive, problem gambling and when he was engaged in more controlled, leisurely gambling. ${ }^{66}$ The Court was, thus, firmly against recognizing a duty of care toward the plaintiff in the circumstances as presented. $^{67}$

On the other hand, the circumstances in Preston v. Star City Pty Limited (No. 3), ${ }^{68}$ led Justice Hoeben to conclude that the plaintiff's claim could proceed to trial. In that case, the plaintiff was known by the defendant to be a high-loss gambler; nevertheless, the defendant provided him with free alcohol (and perhaps even substituted alcoholic drinks for the nonalcoholic drinks the plaintiff had ordered), allowed him to gamble while intoxicated, and engaged in a number of inducements intended to preserve the plaintiff's status as a "high roller." ${ }^{69}$ The plaintiff lost approximately $\$ 3$ million at the defendant's casino. Justice Hoeben found that these facts could constitute the extraordinary circumstances in which a duty of care toward a problem gambler might arise. This case could be instructive for a potential duty of care in Ontario.

Ibid at para 203. We note here that licenced alcohol providers have not been able to make similar arguments to avoid liability (such that, even if they had stopped serving a patron, he would have gone to another establishment and continued drinking). Although it may be true that the patron would have consumed elsewhere, each licenced establishment is responsible for its contribution to the plaintiff's intoxication. See e.g. Hague v Billings (1993), 13 OR (3d) 298 (CA). [2001] NSWCA 234.

Ibid at para 27.

Ibid at para 48

Ibid.

Ibid at para 143. We question how meaningful a "choice" is made by a self-identified excessive gambler who is chasing his losses.

66 Ibid at para 150. Note that, unlike in the circumstances we are proposing, the plaintiff was not enrolled in a loyalty or similar rewards program, which would have provided more detailed information about his gambling patterns. Moreover, the club did not engage in especially predatory practices.

See also Foroughi $v$ Star City Pty Limited, [2007] FCA 1503.

[2005] NSWSC 1223.

Ibid at para 16. 
However, in the subsequent case of Kakavas v. Crown Melbourne Limited, ${ }^{70}$ which was pleaded as an action in equity for unconscionable conduct, the High Court of Australia rejected the plaintiff's claim and essentially affirmed its position on the plaintiff's responsibility for his own actions. The Court did so in spite of evidence that the defendant had induced the plaintiff, a known high-loss gambler, by offering him sporting tickets, free flights on a corporate jet, free food and drinks, hotel accommodation, permission to place extra-large bets, and special rebates on losses. An employee of the defendant had also encouraged the plaintiff to provide misleading documentation from a psychologist indicating that the plaintiff had the "all clear" to recommence gambling following both voluntary and involuntary exclusion orders. ${ }^{71}$ Nevertheless, the High Court concluded that the defendant did not have the relevant "predatory" state of mind to justify the claim of unconscionable conduct. $^{72}$

Finally, the recent New Zealand case of Sinclair v. New Zealand Racing Board ${ }^{73}$ considered the claim of an "emotionally vulnerable," middle-aged, single woman who had been convinced by a charming problem gambler to loan him money, which he subsequently lost to the defendants through bets on horse racing. The judge used the two-stage approach to consider whether a novel duty of care should be recognized. With respect to proximity, Justice Brown found that the defendant had sufficient control over the gambler and had exercised its powers to exclude him on a previous occasion. However, as the defendant had no dealings with the plaintiff, she was only one member of a vast, indeterminate class of people who might fall prey to one of the gambler's schemes. ${ }^{74}$ This was insufficient to create a relationship of proximity. At the second stage of the duty analysis, Justice Brown further concluded that imposing a duty of care would create the risk of indeterminate liability. ${ }^{75}$ This ultimate conclusion is not surprising, given that the plaintiff was once-removed from the casino $;{ }^{76}$ Sinclair is otherwise broadly supportive of casinos' responsibility for gamblingrelated harm.

\section{B. CANADA}

In Canada, the issue of liability for gambling-related harm has previously arisen in the context of self-exclusion provisions. Most notably, in Dennis v. Ontario Lottery and Gaming Corporation, ${ }^{77}$ the Ontario Court of Appeal refused to certify a class action by gamblers who had completed OLG's self-exclusion forms but had nevertheless been allowed to enter casinos and then suffered gambling losses. The self-exclusion program had been created by OLG as a means for gamblers to acknowledge their problematic behaviour and take steps to

[2013] HCA 25 [Kakavas]. The plaintiff claimed losses of $\$ 30,000,000$.

Ibid at paras 63-65.

Ibid at para 160. In other words, the defendant did not knowingly exploit the plaintiff's weaknesses. But see Bigwood, supra note 10, who questions the High Court's restrictive interpretation of unconscionability.

[2015] NZHC 2067.

Ibid at para 88. Justice Brown rejected the argument that single, emotionally vulnerable, financially independent women was a sufficiently identifiable class to support an argument of proximity.

Ibid at para 96. Justice Brown also noted the statutory problem gambling "levy" that the New Zealand Racing Board already pays to support the development and delivery of a problem gambling strategy (ibid at para 97). See Gambling Act 2003 (NZ) 2003/51, s 319.

Similar issues arose in Paton Estate, supra note 1, as the gambler in the case had misappropriated funds belonging to the plaintiff.

2013 ONCA 501 [Dennis CA], aff'g 2011 ONSC 7024 (Div Ct), aff'g 2010 ONSC 1332 [Dennis SC]. 
curtail it. Enrolment required individuals to complete a form and provide photo identification, which was then photocopied and circulated to security personnel. Security could then deny self-excluders entry into gambling facilities or eject them if found on the premises. This form of "memory-based enforcement" was relatively weak ${ }^{78}$ and gamblers like Mr. Dennis gained re-entry despite the self-exclusion agreements.

The motions justice, Justice Cullity, was prepared to find that OLG owed a duty of care to gamblers who had enrolled in the self-exclusion program. He based his finding on several alternative arguments. First, he found that the situation was analogous to other cases where a public authority had created a policy but was negligent in implementing that policy. ${ }^{79}$ Second, he suggested that OLG had assumed responsibility for problem gamblers through its "repeated representations of its commitment to assist problem gamblers and the specific steps it undertook to implement the self-exclusion program for [their] benefit." ${ }^{\prime \prime 0}$ Third, and of particular relevance to this article, Justice Cullity noted that "by making gambling facilities available to the public, OLG created an environment that was inherently dangerous and would inevitably stimulate latent problem gambling propensities in vulnerable individuals." ${ }^{81}$ Justice Cullity was specifically comparing the duty owed by casinos to that owed by licenced establishments. ${ }^{82}$

Also important in Dennis was Justice Cullity's rejection of the defendant's argument that the plaintiffs' personal autonomy weighed against a finding of proximity. Given that problem gambling was presented as a behavioural disorder involving a "psychologically uncontrollable preoccupation and urge to gamble," and that OLG had publicly acknowledged its severity, Justice Cullity concluded that personal autonomy could not be decisive in the analysis of proximity. ${ }^{83}$ Finally, he did not believe that the plaintiffs' claim gave rise to a risk of indeterminate liability, since it involved only persons who had entered into self-exclusion agreements with OLG. ${ }^{84}$

Nevertheless, certification was denied in Dennis because the claim rested on the assertion that the respective plaintiffs were vulnerable, pathological gamblers. This could only be determined on a case-by-case basis, and so it was an inappropriate situation for a class proceeding. ${ }^{85}$ Further, the Court would not accept the statistical evidence that 87 percent of self-excluded individuals were likely to be problem gamblers as a substitute for an inquiry into the personal circumstances of each class member. ${ }^{86}$

Dennis SC, ibid at para 156. An expert affidavit before the motions judge noted that it was impossible for security personnel to memorize and identify the more than 10,000 self-excluded individuals in Ontario (ibid at para 60). This can be contrasted to the more effective self-exclusion system used in most European countries, which uses an electronic database and requires all patrons to provide identification (and thus be cross-checked against the database) on entry to a casino.

Dennis SC, ibid at para 135.

Ibid at para 136.

Ibid at para 145 .

Ibid at para 142 .

Ibid at para 149 .

Ibid at para 157.

Dennis CA, supra note 77 at paras 3-4.

Ibid at paras $30-31$. 
In the British Columbia case of Ross v. British Columbia Lottery Corporation, ${ }^{87}$ Justice Truscott held that the legislated self-exclusion system gave rise to a duty of care by casinos "to exercise all due diligence to prevent and not knowingly permit any person who has been barred from the casino ... from entry or being present in the casino or participating in casino games. ${ }^{" 88}$ He explained that, while the defendants did not create a risk, they did "assist in attempting to reduce the risk of the plaintiff continuing to gamble." 89 Notably, Justice Truscott also found that casinos must assume that those entering self-exclusion agreements are problem gamblers. ${ }^{90}$ Nevertheless, Justice Truscott concluded that the defendant had satisfied the standard of care, as the self-exclusion program met or exceeded industry practice in North America at the relevant time. ${ }^{91}$ He also described the plaintiff as "the author of her own misfortune," 92 especially because she had made attempts to evade detection by casinos after signing a self-exclusion agreement. Justice Truscott alluded to the notion that the plaintiff's claim amounted to the creation of an insurance scheme for those in the selfexclusion program, concluding that, "[t]o award her these monies simply because she was in the self-exclusion program when every other gambler not in the program is not entitled to this recovery, would be to encourage every other gambler to join the self-exclusion program in order to have this claim." 93

Finally, the Nova Scotia Court of Appeal decision in Burrell v. Metropolitan Entertainment Group ${ }^{94}$ also relied heavily on the province's self-exclusion program. Justice Fichaud explained that self-exclusion provisions help strike a balance between personal autonomy and the recognition that some gamblers may lose the ability to control their behaviour. They give individuals with a gambling problem the opportunity to ban themselves from casinos and create a "bilateral responsibility of both the individual and the [casino] operator who knowingly permits the contravention of that prohibition." 95 In Burrell, the plaintiff unsuccessfully sued for gambling losses that he had incurred prior to entering into a self-exclusion agreement. The Court was not willing to extend a duty of care to gamblers who had not entered self-exclusion agreements, as it would be difficult for casinos to distinguish problem gamblers from merely frequent gamblers.

Thus, there had not been a successful reported claim for gambling-related losses in Canada prior to Paton Estate, which was itself only an interlocutory decision on a motion to strike out the claim. ${ }^{96}$ In Paton Estate, the relevant gamblers were not parties to a self-

2014 BCSC 320 [Ross].

Ibid at para 533. The plaintiff also brought unsuccessful claims for unjust enrichment and breach of fiduciary duty.

Ibid at para 538

Ibid at para 541 .

Justice Truscott admittedly referred to the facial recognition system as "rudimentary" (ibid at para 568).

Nevertheless, a number of expert witnesses testified that it was the industry standard in North America. Among other things, these experts testified that checking patrons' ID on entry to the casino would be excessively time-consuming and could be considered an invasion of privacy. We find this argument rather unpersuasive, given that ID procedures must be in place to prohibit minors from entering casinos. As described in Part V.C, below, several other jurisdictions use ID checks to enforce their self-exclusion programs.

Ibid at para 573 .

Ibid at para 575 .

2011 NSCA 108.

Ibid at para 42 .

Nevertheless, the authors are personally aware of several cases that were settled by OLG prior to trial. See also Andrew Chung, "Casinos Not Taking Chances in Court," The Toronto Star (5 August 2007), online: <https://www.thestar.com/news/2007/08/05/casinos_not_taking_chances_in_court.html $>$. 
exclusion agreement, but one of them lost over $\$ 3$ million at the defendant's casinos (which she had stolen from the plaintiffs). ${ }^{97}$ The case presented an extra challenge in terms of establishing a proximate relationship because the plaintiffs were third parties whose money the gamblers had lost. As in the New Zealand case of Sinclair, the plaintiffs in Paton Estate were once-removed from any interactions with the casino. ${ }^{98}$

The motions judge had found that there was insufficient proximity to ground a duty of care because there was nothing to differentiate the problem gamblers from anyone else who placed bets at the casino. ${ }^{99}$ A majority of the Court of Appeal disagreed and allowed the action to proceed. Justice Pardu wrote, "I agree that casinos cannot be expected to conduct an individualized assessment of each of their customers to determine the wisdom of the decision to gamble. However, more may be expected when an individual is obviously addicted to gambling and out of control." ${ }^{\prime 100}$ In this respect, we note that the gambler was a loyalty program member and that a small handful, if any, of Ontario residents can afford $\$ 3$ million in betting losses. ${ }^{101}$ It is, thus, reasonable to argue that the casino ought to have known that the gambler's excessive consumption was likely predictive of foreseeable harm and to have taken some steps to assess her ability to continue gambling. ${ }^{102}$

In assessing proximity, Justice Pardu compared casinos to licenced establishments, which owe a duty of care to their patrons and also to any third parties that intoxicated patrons may injure. Among the factors giving rise to proximity in commercial host cases are the creation of risk and the defendant's ability to profit from over-serving patrons. Justice Pardu found these aspects to be similarly applicable to casinos. As discussed below, we believe that Justice Pardu's analogy is apt.

In dissent, Justice Hoy stressed that there was no interaction between the plaintiffs and OLG, ${ }^{103}$ and there was no reason for the casino to suspect that the plaintiffs, in particular, were at risk. She also stressed that the relevant statutory duty was one owed to "the public at large and not to any specific gambler or people connected to specific gamblers." 104 Justice Hoy also distinguished the alleged duty from that owed by commercial hosts on the basis that a patron's intoxication poses a risk of physical injury, not economic loss. ${ }^{105}$ She cautioned that the proximity analysis is particularly stringent in cases where the plaintiff is alleging pure economic loss and that the relationship at issue in Paton Estate was too tenuous.

While the case focused on one particular gambler, Ms. Spinks, who had misappropriated the plaintiffs' trust funds, she had also given some funds to her mother, who in turn lost them by gambling.

Paton Estate thus presents a less-than-ideal factual basis on which to establish that casinos owe a duty of care. Presumably, it will essentially require the plaintiffs to establish that the duty of care is owed to third parties who could foreseeably suffer harm as a result of a patron's excessive gambling. That said, a defrauded estate might appear to be a more sympathetic plaintiff than the gambler herself.

Paton Estate SC, supra note 1 at para 24.

Paton Estate CA, supra note 1 at para 35.

See supra note 48.

For example, she had falsely claimed to be a lawyer. Her occupational status could easily have been verified through the law firm's website or the Law Society.

This contention ignores that the patron signed up for the loyalty program and received correspondence containing inducements to increase her gambling in response to her measured gambling metrics.

Paton Estate CA, supra note 1 at para 131.

Ibid ("[n]o duty to ensure that a patron does not drink away her or his family's earnings has been recognized" at para 139). 
Accordingly, the current situation in Canadian law is one that is cautiously open to claims against casinos by patrons who are loyalty program members and whose gambling has become excessive to the point that harm is foreseeable. The courts seem genuinely receptive to the argument that casinos owe a duty of care to those who have entered into self-exclusion agreements, although the courts have shown considerable deference to casinos in assessing whether they have met the standard of care. ${ }^{106}$ These cases are based on an apparent assumption of responsibility by the defendant to prevent the plaintiff from gambling and on the gambler's detrimental reliance on the agreement. The more novel case, and the one on which we focus below, is a general duty of care owed to those who engage in extreme "overconsumption" of gambling at a defendant's casino and are members of the casino's loyalty program. The majority in Paton Estate was willing to entertain the possibility of liability; it remains to be seen which circumstances will justify imposing a duty of care.

\section{APPLying THE TEST IN COOPER V. HOBART}

The discussion that follows focuses primarily on the duty of care owed by casinos. However, as indicated, since casinos in Ontario are ultimately owned by OLG, our analysis also raises certain aspects of public authority liability and the statutory framework.

\section{A. ForESEEABILITY}

The foreseeability stage of the Cooper test does not typically present a challenge for plaintiffs, and actions are rarely struck out at this stage. ${ }^{107}$ The recent Supreme Court of Canada decision in Rankin (Rankin's Garage \& Sales) v. J.J. ${ }^{108}$ indicates that foreseeability is important because it "would simply not be just to impose liability in cases where there was no reason for defendants to have contemplated that their conduct could result in the harm complained of." 109 The plaintiff must establish that it was reasonably foreseeable to the defendant that its failure to take care could cause a given type of damage to someone in the plaintiff's position. ${ }^{110}$

In terms of gambling, the plaintiff's economic losses seem to be eminently foreseeable: indeed, casinos can only be profitable to the extent that their patrons lose more money than they win. The casino's gains axiomatically come at the expense of their patrons. Moreover, in cases where the casino is aware that this plaintiff in particular is gambling large sums of money and induces the plaintiff to continue doing so, it is reasonably foreseeable that the plaintiff will suffer some harm: in the absence of extreme wealth, ever-increasing bets introduce the likelihood of cumulative financial loss. ${ }^{111}$ Then, as losses become extreme, there is an increasing probability that bets will be financed by debt, theft, or other unauthorized sources, with the attendant likelihood of harm to health and economic well-

In contrast to commercial hosts, whose standard of care is based on independently-developed server training programs, casinos have been allowed to fall back on their own industry standards in defining the standard of care.

See GHL Fridman et al, The Law of Torts in Canada, 3d ed (Toronto: Carswell, 2010) at 302-303.

2018 SCC 19 [Rankin's Garage].

Ibid at para 22.

Ibid at para 24.

See supra note 48. 
being. ${ }^{12}$ In the language of Rankin's Garage, there is ample reason for casinos to contemplate that their conduct can result in economic loss to the plaintiff.

\section{B. PROXIMITY}

Proximity is a notoriously difficult concept to define and has been subject to extensive criticism in Canada and elsewhere. ${ }^{113}$ At the same time, it has taken on central importance in the Canadian duty jurisprudence since Cooper. The Supreme Court in Cooper stressed that proximity is concerned with the relationship between the plaintiff and defendant: this relationship must be "close and direct," and new relationships of proximity can be determined by analogy to established categories. ${ }^{114}$ According to Chief Justice McLachlin and Justice Major, proximity is assessed by

looking at expectations, representations, reliance, and the property or other interests involved. Essentially, these are factors that allow us to evaluate the closeness of the relationship between the plaintiff and the defendant and to determine whether it is just and fair having regard to that relationship to impose a duty of care in law upon the defendant. ${ }^{115}$

Furthermore, the Supreme Court in Cooper acknowledged that "[t]he factors which may satisfy the requirement of proximity are diverse and depend on the circumstances of the case. One searches in vain for a single unifying characteristic." 116

Unsurprisingly, the analysis of proximity between casinos and their patrons is multifaceted. On the one hand, casinos invite patrons into their facilities, have direct interactions with them, and engage in regular financial transactions with them. On the other, the relationship between casinos and their patrons is inherently competitive (each is trying to win money from the other), ${ }^{117}$ so the "expectations" between the parties (to use the language of Cooper) are generally that each will look out for its own interests. ${ }^{118}$ Nevertheless, as discussed below, we believe there are sufficiently exceptional circumstances in which casinos should have a private law duty to intervene to prevent severe gambling-related harm.

The methodology of Cooper suggests that novel categories of duty can be established by analogy to established categories. Accordingly, the first part of our proximity analysis outlines the analogous category of the duty of care owed by establishments licenced to serve alcohol (also known as commercial hosts) toward their patrons. This analogy was raised in both Dennis and Paton Estate. Nevertheless, in Deloitte \& Touche v. Livent (Receiver of),

See Colin S Campbell, Timothy F Hartnagel \& Garry J Smith, The Legalization of Gambling in Canada (Report prepared for the Law Commission of Canada); Garry Smith \& Rob Simpson, "Gambling Addiction Defence on Trial: Canadian Expert Witness Perspectives" (2014) 3 Int'l J Criminology \& Sociology 319 .

113 For example, the eminent John G Fleming referred to it as a "vacuous" test: "The Negligent Auditor and Shareholders" (1990) 106 Law Q Rev 349 at 351. See also the pre-Cooper cases of Canadian National Railway Co v Norsk Pacific Steamship Co, [1992] 1 SCR 1021; Hercules Managements Ltd v Ernst \& Young, [1997] 2 SCR 165. The High Court of Australia has dispensed with proximity entirely: Miller $v$ Miller, [2011] HCA 9.

Cooper, supra note 5 at paras 31-32.

Ibid at para 34.

Ibid at para 35 .

This is true even though OLG claims to be providing "entertainment."

But see the text relevant to note 144 , below. 
the Supreme Court warned that analogous categories should be carefully delimited so that important residual policy considerations do not go unexamined. ${ }^{119}$ Policy considerations are examined in Part V.C, below.

\section{The ANAlogous CATEgORY OF LiCENCED ESTABLishMENTS}

In our view, there are three main similarities between the categories of licenced establishments and casinos to their respective patrons. First, both licenced establishments and casinos are obliged by statute to adopt responsible practices. In the case of licenced establishments, the most relevant obligation is to not "permit drunkenness ... to occur on the premises." ${ }^{120}$ As described below, this requires licensees to monitor and control patrons' consumption so as to prevent over-consumption and thereby guard against foreseeable harm. In the case of OLG, the statutory obligation is a more vaguely defined duty to "promote responsible gaming with respect to lottery schemes" and "ensure that anything done ... is also done for the public good and in the best interests of the Province."121

Second, as a corollary to their respective statutory obligations, both have at least some obligation to monitor patrons' consumption of alcohol or gambling. Indeed, as described in Part III.C.2, above, casinos have extensive loyalty programs that carefully track patrons' gambling and induce them to gamble more. Requiring them to identify those with repeated or substantial losses should add little to their existing functions. Their liability would be limited to situations where they ignore or exacerbate obvious patterns of excessive gambling, where harm is reasonably foreseeable.

Third, both enterprises are subject to a perverse incentive, whereby they stand to maximize profit by encouraging patrons to consume excessively and, in the case of gambling, to potentially exceed their financial means. Importantly with respect to licenced establishments, liability in tort has helped to provide additional "teeth" to the statutory prohibition on the over-service of alcohol and to counter what would otherwise be an unconstrained financial incentive to take advantage of intoxicated patrons. A similar duty of care on casinos would more meaningfully implement OLG's own publicized mandates and codes of conduct ${ }^{122}$ and the Registrar's Standards for Gaming. ${ }^{123}$

$119 \quad$ Livent, supra note 6 at para 28.

120 See e.g. Liquor Licence Act Regulations, supra note 22, s 45(1). As noted previously, this has been interpreted as requiring licenced establishments to prevent drunkenness.

121 Ontario Lottery and Gaming Corporation Act, 1999, supra note 8, ss 0.1(c)-(d). See also ACGRPPA, supra note $15, \mathrm{~s} 3(3)$. This is supplemented by a range of voluntary undertakings to "live up to high standards of fairness and ethical behaviour," promote accountability and transparency, and so on: see Ontario Lottery and Gaming Corporation, Corporate Social Responsibility Report 2015-16 (Toronto: OLG, 2017) at 14 . Some provinces have statutory provisions that are similar to the prohibitions in liquor licencing legislation against serving intoxicated patrons. For example, the Nova Scotia Casino Regulations, NS Reg 40/95, s 20(1)(c), contained a provision (now repealed) prohibiting casino operators from allowing individuals to gamble "who appear to be addicted to gambling." (Toronto: OLG, 2016); Ontario Lottery and Gaming Corporation, "Our Mission \& Values," online: $<$ https://about.olg.ca/our-mission-values/>.

123 Alcohol and Gaming Commission of Ontario, "Registrar's Standards for Gaming” (Toronto: AGCO, 2017). 
Canadian courts have recognized that licenced establishments owe a duty of care to their patrons for over four decades. ${ }^{124}$ In Jordan House Ltd. v. Menow, ${ }^{125}$ the Supreme Court of Canada found the defendant hotel liable for ejecting an intoxicated patron who was subsequently struck by a negligent driver when he was walking home along the highway. Justice Laskin's majority opinion stressed the staff's personal knowledge of the plaintiff's tendency to become intoxicated and boisterous. The majority also noted that, contrary to liquor licencing legislation, hotel staff had served Mr. Menow past the point of intoxication and had ejected him onto a dangerous highway when they knew he had no safe transportation home. The hotel staff could have easily protected Menow by arranging transportation, calling the police, or allowing him to spend the night in the hotel. The majority's opinion was, thus, relatively fact-specific. ${ }^{126}$

In contrast, Justice Ritchie's brief minority opinion proposed a broader duty of care owed by commercial hosts: not only did the hotel staff have a duty to protect Menow once he became intoxicated, they also had a duty to prevent his intoxication in the first place. This wider duty acknowledges that foreseeable risk is inherent in the over-service and excessive consumption of alcohol. ${ }^{127}$

It was Justice Ritchie's minority opinion that was adopted and expanded in the lower courts. Notably, in Picka Estate v. Porter, ${ }^{128}$ the Ontario Court of Appeal found that the duty to prevent intoxication includes a duty to monitor patrons' consumption, even if the commercial host has had no prior dealings with a particular drinker. The defendant in Porter was a Legion Hall that served drinks from behind a partition, such that it was impossible to track patrons' consumption or observe them for signs of impairment. Mr. Porter became intoxicated at the Legion before causing a fatal crash. The Legion argued that it could not be held liable because, unlike the defendant in Jordan House, it was not aware of Porter's drunkenness. The Court of Appeal rejected this submission and held that licenced establishments have a duty to implement practices to ensure that patrons are not served beyond the point of intoxication (for example, they must prevent intoxication). Indeed, in a later case, ${ }^{129}$ the judge accepted the rigorous Server Intervention Program (SIP) as reflective of the appropriate standard of care; among other things, this program requires servers to count drinks in order to ensure that patrons' consumption remains below specified risk thresholds. ${ }^{130}$

See generally Robert Solomon \& John Payne, "Alcohol Liability in Canada and Australia: Sell, Serve and Be Sued" (1996) 4:2 Tort L Rev 188; Erika Chamberlain, "Alcohol Provider Liability in Canada and the United Kingdom: Legal and Cultural Influences" (2004) 33:2 Comm L World Rev 103. (1973), [1974] SCR 239 [Jordan House].

126 Indeed, Justice Laskin explained that the Supreme Court's decision did not impose "a duty on every tavern-owner to act as a watch dog for all patrons who enter his place of business and drink to excess" (ibid at 250, citing Menow v Honsberger (1969), 7 DLR (3d) 494 at 503 (Ont HC)).

127 This conclusion is consistent with the empirical evidence, which indicates that alcohol is associated with higher risks of not only motor vehicle crashes, but also violence, falls, drowning, suicide, fires, and workplace accidents. See generally R Solomon et al, "Alcohol, Trauma and Impaired Driving," 4th ed (Oakville: MADD Canada, Centre for Addiction \& Mental Health, and Canadian Centre on Substance Abuse, 2009), online: <https://www.madd.ca/english/research/real_facts.pdf>. [1980] OJ No 252 (QL) (CA) [Porter].

Dryden (Litigation guardian of) $v$ Campbell Estate (2001), 11 MVR (4th) 247 (Ont Sup Ct J). Ibid at paras 94-96. 
This duty to monitor all patrons is important to consider when comparing licenced establishments and casinos. As described above, several Commonwealth courts have rejected liability on the basis that casinos cannot possibly identify or diagnose pathological gamblers, and Canadian authors have similarly focused their attention on a casino's personal knowledge of a particular gambler's problem "condition." 131 In our view, this is not the point; neither is commercial host liability dependent on licenced establishments either identifying or diagnosing alcoholics. The duty of care requires licenced establishments to monitor all patrons' consumption so as to not serve them beyond the point of intoxication. Similarly, casinos should have some duty to monitor and identify patrons whose gambling metrics reasonably indicate excessive consumption and the potential for foreseeable harm. ${ }^{132}$ While casinos already monitor consumption as part of their loyalty programs, they do not use this information to intervene when the risk of harm materializes. Instead, they apply upward pressure on patrons' gambling, which would be akin to licenced establishments enticing patrons - including those who are obviously intoxicated - to continue drinking without restraint.

A central feature giving rise to proximity between licenced establishments and their patrons is the potential for establishments to profit from the over-service of alcohol. For instance, in distinguishing commercial hosts from social hosts in Childs v. Desormeaux, ${ }^{133}$ the Supreme Court of Canada stressed the need to counter the financial incentive of overservice:

\footnotetext{
Unlike the host of a private party, commercial alcohol servers have an incentive not only to serve many drinks, but to serve too many. Over-consumption is more profitable than responsible consumption. The costs of over-consumption are borne by the drinker him or herself, taxpayers who collectively pay for the added strain on related public services and, sometimes tragically, third parties who may come into contact with intoxicated patrons on the roads. Yet the benefits of over-consumption go to the tavern keeper alone, who enjoys large profit margins from customers whose judgment becomes more impaired the more they consume. This perverse incentive supports the imposition of a duty to monitor alcohol consumption in the interests of the general public. ${ }^{134}$
}

This passage was quoted with approval by Justice Pardu in Paton Estate, where she indicated that it applies "with equal force to casino operators." 135

This passage is also critical to overcoming the traditional common law rule against imposing liability for "omissions," which is based largely on Victorian values such as personal responsibility and individual autonomy. According to this rule, defendants do not typically have a private law obligation to protect plaintiffs from being harmed by third parties or themselves. However, there are a range of exceptions to this rule against affirmative duties, including where the defendant is in a position of control over the plaintiff or over a

See Sasso \& Kalajdzic, supra note 4 at 20-21; Cameron, supra note 4 at 557-58.

Admittedly, this may be difficult with respect to patrons who gamble at a range of facilities, such that any given casino is unaware of a patron's gambling patterns. However, that does not excuse the conduct of casinos that are already monitoring a patron's gambling through a loyalty program.

Supra note 6.

Ibid at para 22.

Paton Estate CA, supra note 1 at para 42. 
third party who might injure the plaintiff, ${ }^{136}$ where the defendant has assumed responsibility for the plaintiff, ${ }^{137}$ where the defendant has created a risk of harm to the plaintiff, ${ }^{138}$ where the defendant has induced the plaintiff's reliance through his or her representations, ${ }^{139}$ and, less consistently, where the plaintiff is in a particularly vulnerable position. ${ }^{140}$

In the case of licenced establishments, an affirmative duty is imposed because the overservice of alcohol creates a dangerous situation that increases the risk of harm both to the drinker and to those the drinker might encounter on the road or interpersonally. ${ }^{141}$ Moreover, the defendant is in a position of control, as it has the ability to stop serving intoxicated patrons and eject them from the premises. Finally, the Canadian cases on alcohol-related liability have stressed the vulnerability of patrons, including on account of their youth and their intoxicated states. Justice Wilson famously wrote in Crocker v. Sundance Northwest Resorts Ltd:

The common thread running through these cases is that one is under a duty not to place another person in a position where it is foreseeable that that person could suffer injury. The plaintiff's inability to handle the situation in which he or she has been placed - either through youth, intoxication or other incapacity - is an element in determining how foreseeable the injury is. ${ }^{142}$

The law in this field thus recognizes that, the more alcohol that patrons consume, the less likely they are to make responsible decisions and the greater the duty on the alcohol provider to take care for their safety.

Similarly, we believe that certain circumstances justify imposing an affirmative duty on casinos toward their patrons. Casinos are also in a position of control, in that they can prevent a patron from betting, constrain excessive betting, or, more likely, eject the patron from the casino and prevent re-entry. ${ }^{143}$ Instead, as described earlier, casinos apply constant pressure to gamble more in the absence of any mechanisms to limit harm. Consider, for example, a casino patron who has already lost considerable amounts and is chasing those losses, both of which can be ascertained from loyalty program data. Chasing in order to recover losses that could not be afforded is an act of desperation in which, by definition, the patron makes increasingly irrational decisions. By analogy to licenced alcohol providers, the casino should have an even greater duty to intervene, as such patrons will predictably incur ever more serious losses if permitted to continue gambling.

See e.g. Funk Estate v Clapp (1988), 54 DLR (4th) 512 (BCCA) (prison authorities owed duty toward prisoner who committed suicide); and the classic English case of Dorset Yacht Co Ltd v Home Office, [1969] 2 QB 412 (CA), aff'd [1970] AC 1004 (defendant Borstal supervisors owed duty to control young offenders in their custody and prevent them from damaging the plaintiffs' yacht). See Barrett v Ministry of Defence, [1995] 1 WLR 1217 (Eng CA), in which senior officers had an intoxicated soldier taken back to his room and put in the recovery position, where he later suffocated on his own vomit. While the court stressed that the plaintiff was responsible for his own drunkenness, it found that a duty of care arose when the officers took control of his safety. See e.g. Wince (Guardian ad litem of) v Ball (1996), 136 DLR (4th) 104 (ABQB). Fullowka, supra note 6 (replacement workers relied on security firm to protect them during a violent strike).

140 See e.g. Williams $v$ Toronto (City), 2016 ONCA 666 (tenants of rooming houses were particularly vulnerable so the City owed an affirmative duty to inform them of their rights with respect to rent reductions).

141 See generally Chamberlain, supra note 124.

142 Crocker $v$ Sundance Northwest Resorts Ltd, [1988] 1 SCR 1186 at 1197. 
The principles of affirmative duties also help to address another common aspect of the alcohol and gambling cases, which is the notion of personal autonomy. Plaintiffs' claims are based, in part, on an argument that the defendants had a duty to protect them from their own decisions to drink or gamble; as described above, the Commonwealth courts have typically stressed the plaintiff's autonomy to make decisions in denying a duty of care toward gamblers. Similar arguments have been made with respect to drinkers; Chief Justice McLachlin wrote in Childs:

\begin{abstract}
Also running through the examples is a concern for the autonomy of the persons affected by the positive action proposed. The law does not impose a duty to eliminate risk. It accepts that competent people have the right to engage in risky activities. Conversely, it permits third parties witnessing risk to decide not to become rescuers or otherwise intervene. It is only when these third parties have a special relationship to the person in danger or a material role in the creation or management of the risk that the law may impinge on autonomy.... The autonomy of risk takers or putative rescuers is not absolutely protected, but, at common law, it is always respected. ${ }^{144}$
\end{abstract}

In our view, the "special relationship" with their patrons arises from casinos' positive actions to induce unrestricted gambling, their ability to profit from excessive gambling, and their ability to control gambling behaviour. This relationship is further intensified in the case of loyalty program members, particularly as their monitored gambling and losses deepen. Casinos are not passive "bystanders" who have no legal obligation to provide assistance; rather, they actively exploit patrons' vulnerabilities, whether cultivated or innate, solely for profit. Moreover, loyalty program databases record all aspects of patrons' gambling, and consult these metrics in selecting increasingly powerful inducements to gamble more. Thus, casinos are not only sufficiently analogous to commercial alcohol providers but interact in a considerably more intense and purposeful manner with their patrons; the element of proximity should therefore be established.

\title{
2. PROXIMITY AND ECONOMIC LOSS
}

The courts are less likely to recognize a duty of care when the harm suffered by the plaintiff is purely economic as opposed to personal injury or property damage. ${ }^{145}$ Thus, one of the oft-cited differences between alcohol-related liability and liability for gambling-related harm is the type of loss suffered. ${ }^{146}$ This gives rise to additional policy considerations, which are discussed below. It also creates potential challenges in the proximity analysis.

The Supreme Court of Canada has generally accepted the five categories of pure economic loss proposed by Professor Bruce Feldthusen in his leading treatise, Economic Negligence (that is, negligent misrepresentation, negligent performance of a service, negligent supply of shoddy goods or structures, relational economic loss, and the liability of statutory public authorities). ${ }^{147}$ Of these, the two that most plausibly apply are the negligent performance of

144 Supra note 6 at para 39 [emphasis added].

145 As noted in Martel Building Ltd v Canada, 2000 SCC 60 at para 35 [Martel Building], "the threshold question whether or not to recognize a duty of care receives added scrutiny [with respect to pure economic loss] relative to other claims in negligence." See also Peter T Burns \& Joost Blom, Economic Interests in Canadian Tort Law (Markham: LexisNexis Canada, 2009) at 393-94. 
a service (for plaintiffs who have signed self-exclusion agreements) and the liability of statutory public authorities (for claims against OLG). Since we propose a broader duty of care, the discussion below focuses on the possibility of recognizing a duty of care outside these established categories. ${ }^{148}$

When assessing new duties of care related to pure economic loss, precedent suggests that the courts will stress the proximity factors of expectations, representations, and reliance. ${ }^{149}$ In cases involving independent parties, a critical factor tends to be the way that they have decided to manage their affairs, including through contractual or quasi-contractual agreements. This largely defines the parties' expectations. While a contractual relationship can sometimes be a good indicator of proximity, in that the parties have "close and direct" interactions, the existence of a contract can also weigh against a finding of proximity because the courts are hesitant to interfere with the parties' agreement. ${ }^{150}$

In this respect, casinos have contracts with their patrons and the terms are reasonably well known: gamblers generally know what they will receive in exchange for their bets. Further, it is inherent to gambling transactions that one party's win will be the other party's loss. As the High Court of Australia observed in Kakavas, "the unmistakable purpose of each party [is] to inflict loss upon the other party to the transaction. Gambling transactions are a rare, if not unique, species of economic activity in a civilised community, in that each party sets out openly to inflict harm on the counterparty." 151 In this general scenario, gamblers cannot expect or rely on the casino to look out for their financial interests.

Nevertheless, we believe there are circumstances where a patron's gambling losses are so far beyond what a reasonable person could expect that an affirmative duty should be imposed. Further, patrons have little or no knowledge of the myriad tactics used by casinos to stimulate gambling, to cultivate ever-increasing involvement, and, potentially, to take advantage of them. Thus, the parties are hardly on equal footing when it comes to the transactions at issue.

Where the patron's loyalty program records indicate an extended and increasing pattern of substantial loss, the totality of which can be linked to foreseeable existing or imminent harm to financial and personal well-being, the casino should have a private law duty to intervene. Certainly, OLG has the authority to intervene and take action. In fact, OLG's website, print, and media publications repeatedly proclaim its commitment to "responsible gambling" and acting in the best interests of customers; ${ }^{152}$ these representations could very well create expectations in some patrons that at least some protective measures will be taken if their gambling becomes excessive. Furthermore, having actively contributed to, if not cultivated, a potentially harmful situation, the casino should not be permitted to seek even greater profits, at least not without obtaining credible assurances of the patron's ability to as "merely analytical tools."

See Cooper, supra note 5 at para 34.

See Burns \& Blom, supra note 145 at 393-94.

Kakavas, supra note 70 at para 25.

See supra notes 121-22. 
absorb current and additional losses. These circumstances are consistent with more general principles of affirmative duties in negligence.

\section{Residual Policy Considerations}

If there is sufficient foreseeability and proximity to give rise to a prima facie duty of care, the analysis will turn to so-called residual policy considerations which might negate that duty. These policy considerations will be argued vigorously in cases involving gamblingrelated harm, because the loss is purely economic in nature and one of the defendants, OLG, is a Crown corporation. This means that any damage awards will ultimately be borne by taxpayers. $^{153}$

Various policy arguments arise regularly in cases involving pure economic loss. One is that financial losses tend to reflect a "zero-sum game," namely, that one person's financial loss is another's financial gain. ${ }^{154}$ There is no net loss to society, only a transfer of wealth. ${ }^{155}$ This is inherent in the activity of gambling and distinguishes economic loss from physical injury, for example, which is generally considered a net societal loss.

Nevertheless, an underlying assumption related to this policy consideration is that imposing a duty of care in these circumstances would "deter socially and economically useful conduct." $" 156$ In a free market society, it is assumed that the individual pursuit of economic advantage leads to a more efficient and profitable state of affairs. It is far from clear, however, that regulated gambling is socially useful conduct. At the provincial level, it simply extracts consumer expenditure, largely from other forms of leisure and entertainment, ${ }^{157}$ while arguably inflicting more net social harm than good. The offsetting health, social, and legal costs are substantial and, at least in part, explain why gambling was criminalized in the first place and subsequently legalized only if conducted and managed by provincial governments.

A related policy argument is that, where arm's length parties engage in financial transactions, they should be treated as promoting their own best interests. It is not for the law of torts to correct circumstances in which one of the individuals has simply made a bad bargain. These arguments are somewhat persuasive in the gambling context. Casino patrons are assumed to be independent adults, who are free to spend their own money as they see fit. Many people reasonably engage in gambling and some achieve satisfactory benefit-for-cost outcomes. To borrow language used in other economic loss contexts, tort law should not be used as an "insurance scheme" for those who handle their own finances poorly. ${ }^{158}$ It is argued that, if unsuccessful gamblers are permitted to recover their losses in tort, there will be no individual incentive to gamble wisely.

No doubt, one of OLG's strategies will be to cite its support of more benign activities in the province, which will suffer if it has to pay damages in gambling-related harm cases. Martel Building, supra note 145 at para 62.

Ibid at para 63.

Ibid at para 64. See also Bruce Feldthusen, “Liability for Pure Economic Loss: Yes, But Why?” (1999) 28:1 UWA L Rev 84 at 102

See OLG's Modernization Plan, supra note 16 at 6, which identifies other types of recreation and entertainment from which it aspired to capture a greater "share of wallet" by, among other things, expanding the number of commercial casinos in the province. Martel Building, supra note 145 at para 68. 
It may well be the case that a large percentage of gamblers obtain acceptable benefits (such as financial gain or entertainment) for their associated costs, and we do not propose a scheme in which these patrons should be insured against loss. However, circumstances are dramatically different for those whose gambling losses become excessive and beyond their means, whose responsiveness to inducements is noted and exploited by the casino, and whose monitored data reasonably indicate the probability of existing or imminent harm. These individuals can no longer be considered on equal footing with casinos; rather, they are particularly vulnerable to manipulation, and their gambling decisions become driven by desperation rather than neutral choices about where to spend discretionary entertainment funds.

Another related policy argument is that a duty of care toward gamblers who experience harm will give rise to indeterminate liability. Again, in the abstract, this may be persuasive. It may be difficult for casinos to confine their liability to a defined class of gamblers; they will potentially be susceptible to litigation from a range of individuals who suffer gambling losses. However, any difficulty in drawing a line should not mean that casinos are immune from liability altogether. ${ }^{159}$ We have argued that liability exposure should be limited to patrons who: (1) are loyalty program members; (2) display extreme metrics of excessive gambling consumption; ${ }^{160}$ (3) were actively subjected to inducements to gamble more; and, perhaps, (4) not subjected to reasonable efforts to confirm financial sustainability or prevent future harm. We contend that such a class is identifiable and relatively small. Arguments about indeterminate liability must also take into account that casinos will only be liable to the extent that their conduct falls below the standard of care. We expect that liability would only be found in egregious cases; for example, when a patron's monitored metrics show substantially increased frequency and duration of gambling sessions, average bet size, and per session losses.

Moreover, it must be remembered that liability is almost entirely within OLG's control. It has the capacity to introduce effective protocols to prevent and intercept excessive consumption and foreseeable harm, as is the case for licenced alcohol providers.

Introducing such expectations to monitor and intervene is by no means without precedent, as demonstrated by practices in other jurisdictions. For example, from 2006 to 2009, Norway substantially reduced the number of EGMs and audiovisual stimuli, banned the use of EGMs between midnight and 6:00 a.m., introduced automatic game interruptions, eliminated cash acceptors and payouts, and fixed upper limits for losses per day and month. Patrons were be egregious cases where the threshold is clearly met. For instance, we are personally aware of a case where the patron gambled 26 days per month, with per-session durations of 24 hours and more, average bet sizes of over $\$ 30,000$ per one-minute hand, losses of over $\$ 1$ million per day, and cumulative losses of over $\$ 10$ million. Over time, lower thresholds could be expected to be defined through subsequent cases, just as the scope for commercial host liability was expanded over the decades following Jordan House, supra note 125 . 
required to have personal gambling cards and, to avoid card sharing, wins were transferred electronically to the patron's bank account. ${ }^{161}$

Further, in 2008 and 2012, Germany enacted federal legislative measures that mandate the involuntary exclusion of patrons reasonably suspected to be at risk of addiction or in financially unstable situations, explicitly recognizing that "the operation of a casino is basically undesirable due to the entailed hazards." 162 Failure to comply opens casinos to claims for losses and consequential damages, and claims of contributory negligence are circumvented by placing the onus on casinos to use involuntary exclusions to keep patrons away. ${ }^{163}$ In order to ensure the enforcement of exclusions, all casino patrons must produce identification at the door. ${ }^{164}$ Thus, German casinos are expected to identify and exclude some of their most lucrative patrons. ${ }^{165}$ In comparison to these provisions, our proposals are relatively modest.

At this stage of the Cooper analysis, a court can also consider policy considerations in favour of imposing liability. ${ }^{166}$ At least two principal arguments can be made here. First, gambling is a heavily regulated activity in Canada. It is criminal except to the extent that it is operated in accordance with provincial regulations, which are aimed, at least in theory, at minimizing harm and encouraging social responsibility. Imposing a duty of care in tort would realize these objectives in a manner similar to the regulation of serving alcohol. Second, as outlined in Part III.B, excessive gambling consumption precipitates a substantial burden of personal and social harm in Ontario each year. As currently operated, it is not the kind of socially beneficial activity that calls for immunity in tort. Rather, it is a public health concern of considerable proportions.

\section{Summary AND CONCluSions}

The majority in Paton Estate indicated that, in some circumstances, casinos might owe a duty of care to their patrons to prevent gambling-related harm. In the analysis above, we have endeavoured to set out those circumstances. In our view, a duty of care should be imposed where a casino knows or ought to know (as a result of loyalty program data) that a patron is engaging in extreme gambling and the casino has no credible reason to believe that the patron's existing or imminent losses are sustainable. Casinos would be liable to the extent that they deliberately ignored or exacerbated the patron's mounting losses. Framed in this way, casinos' liability to gamblers should be rare. There will also certainly be some discounting of liability on the basis of contributory negligence. ${ }^{167}$

See Ingeborg Rossow \& Marianne Bang Hansen, "Gambling and Gambling Policy in Norway — An Exceptional Case" (2016) 111:4 Addiction 593.

Tanja Strohäker \& Tilman Becker, "Casino Gambling in Germany: Development, Legal Conditions and the Exclusion System" (2017) Gambling Research Center at the University of Hohenheim Working Paper at 13, online: $<$ https://www.researchgate.net/publication/323150430 Casino Gambling in_Germany_Development_Legal_Conditions_and_the_Exclusion_System_-Working_Paper>.

Ibid.

Ibid at 10 .

Ibid at 14. See also Nadine R Nowatzki \& Robert J Williams, "Casino Self-Exclusion Programmes: A Review of the Issues" (2002) 2:1 Intl Gambling Studies 3 (for similar measures in the Netherlands).

See Hill, supra note 6.

The defendants might also raise the plaintiff's voluntary assumption of risk; however, we believe that much of this analysis is subsumed in our discussion of the plaintiff's autonomy and personal responsibility. 
This limited duty of care is consistent with the general principles of affirmative duties. Like licenced alcohol providers, casinos contribute to the creation of risk and stand to profit by encouraging excessive consumption. They prey on patrons whose ability to make responsible decisions diminishes as their losses grow and create unmanageable problems. Moreover, while their losses are ostensibly economic, they often lead to mental illness, loss of employment, family breakdown, and, to a lesser extent, bankruptcy, criminal charges, and suicide. There is no persuasive reason to extend immunity to casinos for predatory conduct. As with tobacco and alcohol, the costs that gambling inflicts on individuals and broader society should be borne by those who profit by misrepresenting and exploiting its risks. 
[this page is intentionally blank] 